except for kanamycin, but relatively ineffective against Pseudomonas.

Nine of the 14 patients who had improvement in the macroscopic picture of their urine had complete clearance which was maintained for 1-5 weeks after cessation of therapy.

Side-effects were few and mild.

Our opinion of nalidixic acid is that it is a safe antibacterial agent, clears the organisms sensitive to it quickly, and can be administered repeatedly without serious toxic effect.

We are grateful to Mr. E. Brown and Mr. A. Robertson of Winthrop Laboratories, and Mr. M. C. Willcox for their invaluable technical assistance. We wish to thank the nursing staff of the Promenade Hospital for their co-operation, Mr. H. Hallows and the Southport and District Hospital Management Committeee for their administrative help, and Dr. R. A. Miley and Mr. D. W. Sharp of the Clinical Evaluation Unit of the Bayer Products Company for their advice and guidance.

\section{REFERENCES}

BARLow, A. M. (1963): Nalidixic Acid in Infections of Urinary Tract; Laboratory and Clinical Investigitions, Brit. med. J., ii, 1308.

BUCHBINDER, M., WeBB, J. C., ANDERSON, L. V., and MCCABE, W. R. (1962): Laboratory Studies and Clinical Pharmacology of Nalidixic Acid (Win. 18, 320). Antimicrobial Agents and Chemotherapy p. 308 (American Society for Microbiology, Michigan).

Carroll, G. (1963): Negram (Nalidixic Acid): a new Anti-microbial Chemotherapeutic Agent, J. Urol. (Baltimore), 90, 476.

Deitz, W. E., Froelich, E. J., and Bailey, J. H. (1962): Unpublished data in files of Sterling Winthrop Research Institute.

Garrod, L. P., ShOoter, R. A., and Curwen, M. P. (1954): The Results of Chemotherapy in Urinary Infections, Brit. med. J., ii, 1003.

JAMESON, R. M., and SwinNEY, J. (1963): A Clinical Trial of the Treatment of Gram-negative Urinary Infections with Nalidixic Acid, Brit. J. Urol., 35, 122.
KASS, E. H. (1955): Chemotherapeutic and Antibiotic Drugs in the Management of Infections of the Urinary Tract, Amer. J. Med., 18, 764.

Lesher, G. Y., Froelich, E. J., GRUeTT, M. D., BaILEY, J. H., and BRUNDAGE, R. P. (1962): 1, 8Naphthyridine Derivatives, a New Class of Chemotherapeutic Agents, J. Med. Pharm. Chem., 5, 1063.

Lishman, I. V., and SwinNey, J. (1963): Studies of a New Antibacterial Agent, Nalidixic Acid (Win. 18, 320). A Report of its Use in 60 Cases of Urinary Tract Infection, Brit. J. Urol., 35, 116.

MCCABE, E. S. (1963): Resistant Infections of the Urinary Tract, with Special Reference to a New Urinary Antiseptic and Pyelonephritis Lenta, J. Amer. Geriat. Soc., 11, 975.

McChesney, E. W., Froelich, E. J., Lesher, G. Y., Crain, A. V. R., and Rosi, D. (1964): Absorption, Excretion, and Metabolism of a New Antibacterial Agent, Nalidixic Acid, Toxicol. appl. Pharmacol., 6. 292.

MCGeACHIE, J., and KenNedy, A. C. (1963): Simplified Quantitative Methods for Bacteriuria and Pyuria, J. clin. Path., 16, 32.

RHOADS, P. S., Billings, C. E., and O'CONOR, V. J. (1952): Antibacterial Management of Urinary Tract Infections, J. Amer. med. Assoc., 148, 165.

SLADE, D. A. (1963): A Clinical Trial of Nalidixic Acid (Negram, Win. 18,320) in Thirty-three Patients with Urinary Infections Treated in General Practice, Brit. J. Urol., 35, 125.

Thompson, R. E. M., and RAE, J. (1964): Negram (1 - ethyl - 7 - methyl - 1, 8 - naphthyridine-4-one - 3carboxylic Acid): A new Antibacterial Agent for th8 Treatment of Urinary Infection. Report of a Triax in General Practice, Brit. J. Urol., 36, 42.

TURCK, M., BROWDER, A. A., LINDEMEYER, R. Koㅜㅇ Brown, N. K., ANDERSON, K. N., and PeTERSDORF, R. G. (1962): Failure of Prolonged Treatment of Chronic Urinary-tract Infections with Antibiotics, New Engl. J. Med., 267, 999.

WARD-MCQUAID, J. F. N. C., JiChLINSKI, D., and MACIS, R. (1963): Nalidixic Acid in Urinary Infections, Brit. med. J., ii, 1311.

WATERWORTH, P. M. (1962): A Misapplication of the Sensitivity Test Mandelamine Discs, J. med. Lab. Technol., 19, 163.

\title{
A CLINICAL TRIAL WITH NALIDIXIC ACID ON 22 ACUTE AND CHRONIC URINARY TRACT INFECTIONS WITH FOLLOW-UP FOR I-5 MONTHS
}

\author{
G. C. Misra, M.B., B.S. \\ Research Fellow \\ M. C. WiLlCox, F.I.M.L.T. \\ Chief Technician
}

Liverpool Regional Paraplegic Centre, Southport.

NALIDIXIC acid is one of a series of 1, 8-naphthyridine derivatives. The chemistry, pharmacology and toxicology have been detailed elsewhere, Lishman and Swinney (1963) and Ward-McQuaid, Jichlinski and Macis (1963). In a number of clinical trials published recently this chemotherapeutic agent was shown to be very effective against Gram-negative organisms in urinary tract infec- tions, Lishman and Swinney (1963), Jameson and Swinney (1963), Slade (1963), Barlow (1963), WardMcQuaid and colleagues (1963), Thompson and Rae (1964), McCabe (1963), Carroll (1963) and Gibbon, Benstead and Misra (1965).

On the basis of this information we investigated 22 acute and chronic cases of urinary tract infection with follow-up for 1-5 months. 


\section{Mehods and Material}

These cases were selected at random for trial with nalidixic acid on the basis of clinical and bacteriological findings. Nine of the patients were below 60 years of age, and 13 were over 60 . Fourteen patients were male and eight female. Eighteen patients were given $1 \mathrm{~g}$. nalidixic acid by mouth every six hours until the infection was either cleared or obviously not responding to treatment. The other four patients were given $0.5 \mathrm{~g}$. every six hours. The usual duration of treatment was 5-7 days, but in three cases it was continued for 15 days. Eight acute and six chronic cases took part in this trial.

Daily urine examinations were made from the start of therapy until completion. Midstream specimens were collected except in eight cases who had indwelling catheters where the collection was made in the manner described by Gibbon and colleagues (1965).

Follow-up urine tests were made periodically on those patients who were bacteriologically cleared, this period varying (to date) from one to five months after therapy.

Culture, disc-sensitivity, bacterial and pus cell counts were performed on all specimens as detailed elsewhere (Gibbon and colleagues, 1965). Organisms that developed resistance during therapy were subcultured daily in nutrient broth, up to 15 transferences being made. Disc sensitivity tests using commercially available $30 \mu \mathrm{g}$. nalidixic acid discs, were made on each day's subculture to determine whether any organism would regain sensitivity.

\section{Results}

The diagnosis of the underlying lesion is given in Table 1.

Thirteen patients were cured, seven from the acute cases and six from the chronic (Table 2). The rate of bacteriological clearance is shown in Table 3 . All strains were cleared by the fourth day after commencement of therapy.

The immediate results in the acute cases show a cure rate of $88 \%$ and in the chronic cases one of $43 \%$. Out of the failures, that is one acute case and eight chronic cases, the acute and six of the chronic cases
TABLE 1

Diagnoses of Underlying Lesions in 22 Patients

\begin{tabular}{|c|c|}
\hline DIAGNOSIS & $\begin{array}{c}\text { No. OF } \\
\text { Patients }\end{array}$ \\
\hline $\begin{array}{l}\text { Acute cystitis } \\
\text { Chronic cystitis } \\
\text { Chronic cystitis associated with :- } \\
\text { Bilateral hydronephrosis and hydro-ureter } \\
\text { Carcinoma of the prostate } \\
\text { Carcinoma of the rectum } \\
\text { Diverticulitis of the bladder } \\
\text { Epididymo-orchitis } \\
\text { Paraplegia } \\
\text { Prostatic calculi } \\
\text { Prostatic enlargement } \\
\text { Renal calculi } \\
\text { Renal calculi and epididymo-orchitis } \\
\text { Post-operative cystitis following:- } \\
\text { Cholecystectomy and appendicectomy } \\
\text { Colporrhaphy } \\
\text { Prostatectomy } \\
\text { Vaginal hysterectomy }\end{array}$ & $\begin{array}{l}1 \\
1 \\
1 \\
1 \\
1 \\
1 \\
1 \\
2 \\
1 \\
1 \\
1 \\
1 \\
1 \\
1 \\
1\end{array}$ \\
\hline TOTAL & 22 \\
\hline
\end{tabular}

were clinically much improved and only two showed no improvement. Four chronic cases died from causes unrelated to therapy. One case, who died of cardiovascular disease, was in fact cleared bacteriologically but became re-infected with resistant organisms in the first week after clearance.

Follow-up studies performed on 13 cured cases showed that reinfection was more frequent in chronic than in acute cases. The results are presented in Table 4.

Comparative disc sensitivities of 153 strains of Gram-negative bacilli isolated from urinary tract infections are shown in Table 5. This includes the organisms isolated from the urine of the patients in this series.

The pus cell count of 11 patients showed a complete clearance (Table 6). Ten of these were cleared bacteriologically and the other developed a resistant $E$. coli. Three patients were cleared bacterio-

TABLE 2

Cure Rate on the Basis of Bacteriological and Clinical findings

\begin{tabular}{lcccc}
\hline Nature of infection & $\begin{array}{c}\text { No. of } \\
\text { Patients }\end{array}$ & $\begin{array}{c}\text { Clinically improved but } \\
\text { bacteriologically clear }\end{array}$ & $\begin{array}{c}\text { Clinically cured and } \\
\text { bacteriologically not }\end{array}$ & $\begin{array}{c}\text { Clinically } \\
\text { worse }\end{array}$ \\
\hline Acute & 8 & 7 & clear & 0 \\
Chronic & 14 & $\frac{6}{13}$ & $\frac{6}{7}$ & $\frac{2}{2}$ \\
TOTAL & $\frac{1}{22}$ & & $\frac{6}{7}$ & 2 \\
\hline
\end{tabular}

TABLE 3

Clearance Rate of Organisms in 13 Patients Clinically and Bacteriologically Cured

\begin{tabular}{lccccc}
\hline Organisms & \multicolumn{4}{c}{$\begin{array}{c}\text { Day after commencement of therapy } \\
\text { when clearance was first noted }\end{array}$} & $\begin{array}{c}\text { Total No. } \\
\text { of strains } \\
\text { cleared }\end{array}$ \\
\hline E. coli & $\begin{array}{c}\text { No. of } \\
\text { strains }\end{array}$ & 2nd & 3rd & 4th & 12 \\
Proteus spp. & 12 & 10 & $\overline{2}$ & 2 & 6 \\
Strep. fæcalis & 6 & 3 & $\underline{2}$ & $-\frac{1}{3}$ & $\frac{1}{19}$ \\
TotAL & $\frac{1}{19}$ & $\frac{1}{14}$ & $\overline{2}$ & $\overline{3}$ & 1
\end{tabular}


TABLE 4

Follow-up Showing Maintenance of Clearance and Rate of Re-Infection in 13 Patients

\begin{tabular}{|c|c|c|c|c|c|c|c|c|c|c|c|c|c|c|c|c|}
\hline \multirow[t]{2}{*}{$\begin{array}{l}\text { No. of week when } \\
\text { follow-up was made }\end{array}$} & \multicolumn{2}{|c|}{1} & \multicolumn{2}{|c|}{2} & \multicolumn{2}{|c|}{4} & \multicolumn{2}{|c|}{8} & \multicolumn{2}{|c|}{12} & \multicolumn{2}{|c|}{16} & \multicolumn{2}{|c|}{20} & \multicolumn{2}{|c|}{ 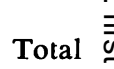 } \\
\hline & A & $\mathrm{C}$ & $\mathbf{A}$ & $\mathrm{C}$ & $\mathbf{A}$ & C & $\mathbf{A}$ & $\mathrm{C}$ & A & $\mathrm{C}$ & $\mathbf{A}$ & $\mathrm{C}$ & $\mathbf{A}$ & $\mathrm{C}$ & $\mathbf{A}$ & \\
\hline No. of cases re-infected & & 1 & 1 & 1 & & 1 & & & & 1 & & & & & 1 & $4 \stackrel{\mathrm{D}}{\mathrm{Q}}$ \\
\hline $\begin{array}{l}\text { No. of cases still maintaining } \\
\text { clearance }\end{array}$ & & & & & 1 & & 1 & & 1 & 1 & 3 & & & 1 & 6 & \\
\hline$A=$ Acute & $\mathrm{C}=\mathrm{Cl}$ & onic & & & & & & & & & & & & & & \\
\hline
\end{tabular}

TABLE 5

Relative Sensitivity of 153 Strains of Organisms to Different Chemotherapeutic Agents

\begin{tabular}{|c|c|c|c|c|c|c|c|c|}
\hline \multirow{2}{*}{ Organism } & \multirow{2}{*}{$\begin{array}{l}\text { No. of } \\
\text { strains }\end{array}$} & \multicolumn{7}{|c|}{ Number of strains sensitive to each chemotherapeutic agent } \\
\hline & & NA. & CH. & NI. & SU. & TE. & MA. & KA. \\
\hline $\begin{array}{l}\text { E. coli } \\
\text { Proteus spp. } \\
\text { Ps. pyocyanea } \\
\text { Atypical coliforms } \\
\text { A. aerogenes }\end{array}$ & $\begin{array}{r}78 \\
58 \\
3 \\
13 \\
1\end{array}$ & $\begin{array}{r}69 \\
50 \\
1 \\
13 \\
1\end{array}$ & $\begin{array}{r}63 \\
36 \\
1 \\
12 \\
1\end{array}$ & $\begin{array}{c}61 \\
21 \\
\text { resistant } \\
11 \\
1\end{array}$ & $\begin{array}{c}39 \\
11 \\
\text { resistant } \\
4 \\
1\end{array}$ & $\begin{array}{c}50 \\
12 \\
\text { resistant } \\
6 \\
1\end{array}$ & $\begin{array}{c}65 / 74 \\
\text { Not tested } \\
3 \\
12 \\
1\end{array}$ & $\begin{array}{r}75 \\
56 \\
3 \\
12 \\
1\end{array}$ \\
\hline TOTAL & 153 & 134 & 113 & 94 & 55 & 69 & $81 / 90$ & 147 \\
\hline $\begin{array}{l}\text { NA }=\text { nalidixic ac } \\
\text { CH }=\text { chloramphe } \\
\text { NI }=\text { nitrofuranto } \\
\text { SU }=\text { Sulphameth }\end{array}$ & $\begin{array}{l}\mu \mathrm{g} .) \\
(100 \mu \mathrm{g} .) \\
0 \mu \mathrm{g} .) \\
(200 \mu \mathrm{g} .)\end{array}$ & & & $\begin{array}{l}\text { TE }= \\
\text { MA }= \\
\mathbf{K A}=\end{array}$ & $\begin{array}{l}\text { acycline } \\
\text { adelamin } \\
\text { amycin ( }\end{array}$ & $\begin{array}{l}\mu \mathrm{g} .) \\
\text { mg.) } \\
\mu \mathrm{g} .)\end{array}$ & & \\
\hline
\end{tabular}

TABLE 6

Behaviour of Pus Cell Clearance in Relation to Bacteriological Clearance

\begin{tabular}{l|c|c}
\hline & Pus cells cleared & Pus cells not cleared \\
With bacteriological clearance & 10 & 3 \\
Without bacteriological clearance & 1 & 8 \\
ToTAL & $\overline{11}$ & $\overline{11}$ \\
\hline
\end{tabular}

logically but the pus cell count although falling, remained at a high level. Two of these became reinfected. The third, while maintaining clearance on culture after three months, still has a high pus cell count but it is falling. The count of the other eight patients was highly variable.

Subculture of strain which acquired resistance:Five strains, three E. coli and 2 Proteus spp. developed resistance during therapy. One Proteus Side Effects.-Three patients had mild reactions to regained sensitivity after the sixth subculture, as judged by the disc technique, but the other four remained resistant.

Side Effects:-Three patients had mild reactions to the drug. One had nausea with drowsiness and mild depression and another, diarrhoea with colicky abdominal pain. These symptoms cleared quickly on stopping the drug. The other patient complained of dizziness which settled after the dosage was reduced.

\section{Discussion}

Our results on the whole are comparable to those of other authors, Barlow (1963), WardMcQuaid and others (1963), Carroll (1963), Garrod, Shooter and Curwen (1964), Kass (1955), Rhoads, Billings and O'Conor (1952), Turck, ơ Browder, Lindemeyer, Brown, Anderson and Petersdorf (1962). The cure rate in acute infec- O

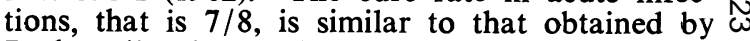
Barlow (1963), Ward-McQuaid and others (1963) and Carroll (1963).

The cure rate of the chronic cases $(43 \%)$ has $\frac{\mathscr{D}}{\mathbb{D}}$ not been as good as that of Barlow (1963) with $\stackrel{?}{?}$ $70 \%$, or Mc-Quaid and others (1963) with $58 \%$, possibly due to the fact that some of our patients were cases of prolonged infection with severely diseased bladders. Those who had urinary obstruc- 
tion due to carcinoma of the prostate, etc. would have, in any case, harboured infection whatever treatment was given.

Our follow-up results are similar to those of Barlow (1963), but we have continued follow-up for a longer period. $6 / 7$ acute and $2 / 6$ chronic cases are still maintaining clearance.

Five resistant strains appeared in five patients, all chronic, and the development of resistance was rapid, irrespective of dosage.

Side-effects, which were mild, were slightly but not significantly higher than those reported by other authors.

Our results of the disc sensitivity tests broadly agree with the results of other authors, only slight variations having been noted (Barlow, 1963), Thompson and Rae, 1964; Ward-McQuaid and others, 1963). The results are similar to those of Gibbon and others (1965).

Daily cultures showed that in those cases who were cleared bacteriologically the organisms disappeared from the urine within four days of commencement of therapy. This was also noted in the series studied by Gibbon and others (1965) and agrees with their suggestion and that of Barlow (1963) that a five day therapy is adequate for clearance of organisms.

Pus cell counts were found to fall progressively as the organisms cleared in the acute cases and in most of the chronic cases who did not have extensively damaged bladders. Only three cases were found who were cleared bacteriologically but in whose urine a high pus cell count persisted. One of these three cases had chronic cystitis, bilateral hydronephrosis and hydro-ureter and this is the patient who is maintaining bacteriological clearance. The second one was a case of chronic cystitis associated with carcinoma of the prostate, and the third case was an old woman with chronic cystitis following recumbency as a result of a fracture of the neck of the femur. These latter two cases were quickly reinfected. The failure to achieve pus cell clearance in these cases is thus explained.

The Proteus which regained sensitivity in vitro was the only one of the five with acquired resistance to do so. It is difficult to assess what importance can be attached to this finding but it indicates that some organisms which become resistant during therapy may eventually become sensitive again. Unfortunately the patient from whom this organism was recovered died from causes unrelated to nalidixic acid therapy, before it was possible to see whether or not the organism had become sensitive in vivo.

\section{Summary}

Twenty-two acute and chronic cases of urinary infection were treated with nalidixic acid. The cure rate, as assessed clinically and bacteriologically has been compared with that of other authors. A follow-up study from 1-5 months has been carried out on the cured cases. Strains which became resistant to nalidixic acid were tested to see whether the resistance was permanent or if they would become sensitive again.

We are grateful to Messrs. C. T. A. Burgess, M.B.E., F.R.C.S., J. Humphreys, F.R.C.S. G. V. Osborne, F.R.C.S., A. C. Wilson, and J. W. Wilson, F.R.C.S. from whose cases the patients in this trial were selected. We wish to thank Dr. J. G. Benstead, Consultant Pathologist to the Southport and District Hospitals Group and Dr. R. A. Miley and Mr. D. W. Sharp of the Clinical Evaluation Unit of the Bayer Products Company for their advice, and $\mathrm{Mr}$. I. Lewis for technical assistance.

\section{REFERENCES}

Barlow, A. M. (1963): Nalidixic Acid in Infections of Urinary Tract. Laboratory and Clinical Investigations, Brit. med. J., ii, 1308.

Carroll, G. (1963): Negram (Nalidixic Acid) a New Anti-microbial Chemotherapeutic Agent, J. Urol. (Baltimore), 90, 476.

Garrod, L. P., Shooter, R. A., and Curwen, M. P. (1954): The Results of Chemotherapy in Urinary Infections, Brit. med. J., ii, 1003.

Gibbon, N. O. K., Benstead, J. G., and Misra, G. C. (1965): A Comparative Study of the Levels of Nalidixic Acid in Plasma and Urine and its Antibacterial Activity in Urinary Infections of Paraplegics, Postgrad. med. J., 41, 501.

JAMESON, R. M., and SwinNEY, J. (1963): A Clinical Trial of the Treatment of Gram-negative Urinary Infections with Nalidixic Acid, Brit. J. Urol., 35, 122.

KASS, E. H. (1955): Chemotherapeutic and Antibiotic Drugs in the Management of Infections of the Urinary Tract, Amer. J. Med., 18, 764.

LishmaN, I. V., and SwINNEY, J. (1963): Studies of a New Antibacterial Agent, Nalidixic Acid (Win. 18, 320). A Report of its Use in 60 Cases of Urinary Tract Infection, Brit. J. Urol., 35, 116.

MCCABE, E. S. (1963): Resistant Infections of the Urinary Tract, with Special Reference to a New Urinary Antiseptic and Pyelonephritis Lenta, $J$. Amer. Geriat. Soc., 11, 975.

RHOADS, P. S., BIllings, C. E., and O'CONOR, V. J. (1952): Antibacterial Management of Uninary Tract Infections, J. Amer. med. Ass., 148, 165.

Slade, D. A. (1963): A Clinical Trial of Nalidixic Acid (Negram, Win. 18,320) in Thirty-three Patients with Urinary Infections Treated in General Practice, Brit. J. Urol., 35, 125.

THOMPSON, R. E. M., and RAE, J. (1964): Negram (1-ethyl-7-methyl-1, 8-naphthyridine-4-one-3-carboxy lic acid): A New Antibacterial Agent for the Treatment of Urinary Infection. Report of a Trial in General Practice, Brit. J. Urol., 36, 42.

TURCK, M., BROWDER, A. A., LINDEMEYER, R. I., Brown, N. K., Anderson, K. N., and Petersdorf, R. G. (1962): Failure of Prolonged Treatment of Chronic Urinary Tract Infections with Antibiotics, New Engl. J. Med., 267, 999.

WARD-MCQUAID, J. E., JICHLINSKI, D., and MACIS, R. (1963): Nalidixic Acid in Urinary Infections, Brit. med. J., ii, 1311 . 